\title{
Antimicrobial Activity of Bioceramic Root Canal Sealers: A Systematic Review
}

\author{
Actividad Antimicrobiana de los Cementos Endodónticos Biocerámicos: \\ una Revisión Sistemática
}

\author{
Cynthia Rodríguez-Niklitschek ${ }^{1,2,3,4,6} ;$ Priscila Chuhuaicura ${ }^{3,5,6}$ \& Gonzalo H. Oporto ${ }^{3,4,5,6}$
}

RODRÍGUEZ-NIKLITSCHEK, C.; CHUHUAICURA, P. \& OPORTO, G. H. Antimicrobial activity of bioceramic root canal sealers: A systematic review. Int. J. Odontostomat., 15(2):348-355, 2021.

\begin{abstract}
Actually, bioceramic endodontic sealers represent an advantageous option for root canals sealing due to their multiple properties. There are several in vitro studies about their antimicrobial properties, however, their comparative antimicrobial potential, compared with other types of endodontic sealers is not entirely clear. The aim of the present research was to perform a systematic review to assess the antimicrobial effectiveness of commercially available bioceramic root canal sealers against Enterococcus faecalis in accordance with the PRISMA statement. A literature search was made in four electronic databases: MEDLINE, ClinicalKey, ScienceDirect and EBSCO. Were included in vitro studies, published in English, between 2015 and 2019. The evaluation of the selected studies was performed by two authors, independently. Four studies were included in the review. EndoSequence ${ }^{\mathrm{TM}}$ (Brasseler USA, Savannah, GA) also available on the market as TotalFill ${ }^{\mathrm{TM}}$ (Brasseler USA, Savannah, GA) and BioRoot ${ }^{\mathrm{TM}}$ were the bioceramic root canal sealers evaluated. The risk of bias was assessed according to the modified CONSORT checklist for preclinical studies. Selected studies reported positive antimicrobial activity against Enterococcus faecalis in the bioceramic sealers evaluated. The less activity was observed on BioRoot ${ }^{\mathrm{TM}}$ sealer. All studies used a planktonic form of Enterococcus faecalis and in vitro laboratory methods of evaluation. The antimicrobial activity reported varies according to the laboratory method used, even for the same sealer, so the existence of false negatives is suggested. This systematic review identified the need for more research into the antimicrobial activity of bioceramic sealers, ideally with models using bacterial biofilms and studies in humans.
\end{abstract}

KEY WORDS: anti-infective agent, bacteria, biofilms, endodontics, enterococcus faecalis, root canal sealer.

\section{INTRODUCTION}

The success of endodontic treatment depends on proper instrumentation and irrigation of root canals, with the objective of to eliminate microorganisms that may be found in them, followed by a correct root canal filling (Nirupama et al., 2014). Although instrumentation and irrigation decrease the number of microorganisms, it is impossible to eliminate all of them from the root canal system in clinical conditions (Zhang et al., 2009; Oporto et al., 2018). Persisting biofilms in the endodontically treated root canal may lead to periapical or periodontal disease (Wang et al., 2014a). Thus, one of the biggest challenges in endodontic treatments is to eliminate or reducing the bacterial biofilms of the root canal system to levels that are compatible with dental and systemic health. Root filling istherefore a critical step of root canal treatment (Nirupama et al.), preferably using dental materials with antimicrobial properties (Wang et al., 2014b). The use of root canal sealers with antimicrobial activity is considered beneficial in reducing the concentration of residual microorganisms (Baer \& Maki, 2010; Nirupama et al.; Kapralos et al., 2018), preventing recurrent root canal infection and assisting the healing of periapical tissues (Singh et al., 2016). Previous studies have investigated

\footnotetext{
${ }^{1}$ Escuela de Odontología, Facultad de Ciencias, Universidad Mayor, Temuco, Chile.

2 Programa de Especialización en Endodoncia, Universidad Mayor, Temuco, Chile.

${ }^{3}$ Centro de Investigación en Ciencias Odontológicas (CICO), Facultad de Odontología, Universidad de La Frontera, Temuco, Chile.

${ }^{4}$ Escuela de Odontología, Facultad de Odontología, Universidad de La Frontera, Temuco, Chile.

${ }^{5}$ Departamento de Odontología Integral Adultos, Facultad de Odontología, Universidad de La Frontera, Temuco, Chile.

${ }^{6}$ Laboratorio de Biología Celular y Molecular, Facultad de Odontología, Universidad de La Frontera, Temuco, Chile.
} 
the antimicrobial activity of root canal sealers (Alshwaimi, 2011) and reported that their freshly mixed are effective against some microorganism, however their antimicrobial effectiveness between 2 and 7 days later has not been reported (Morgental et al., 2011). Within this research, an important number has focused on the comparison of the various materials in vitro (Wang et al., 2014b). Root canal sealers have been reviewed based on their composition, including sealers based on zinc oxide eugenol, calcium hydroxide, glass ionomer, and resin. However, no extensive review of bioceramic-based sealers has been conducted (AlHaddad \& Che Ab Aziz, 2016).

Bioceramic-based root canal sealers have been available for use in endodontics for the past thirty years; the first documented use of a bioceramic as a root canal sealer was an experimental calcium phosphate sealer used in 1984 (Krell \& Wefel, 1984). Today, bioceramics-based root canal sealers have demonstrated an advantage when comparing with other endodontic sealers: their biocompatibility, evidenced in the decreased capacity of these sealers to induce adverse reaction in peripheral tissues (i.e. toxicity, irritation, inflammation, allergy, or carcinogenicity) (Al-Haddad \& Che Ab Aziz) in episodes of extrusion sealer in periapical zone. This property is based on their calcium phosphate content, which results in a chemical composition and crystalline structure similar to tooth and bone apatite materials (Koch \& Brave, 2009).

The available studies have demonstrated that Enterococcus faecalis is one of the microorganisms present in devitalized teeth, especially in teeth with recurrent endodontic infection (Oporto et al.). It is the most common intra-radicular microorganism isolated from periapical periodontitis (Rodríguez-Niklitschek \& Oporto, 2015; Oporto et al.) and is therefore commonly used to test the antibacterial activity of root canal sealers. Other microorganisms, such as Micrococcus luteus, Staphylococcus aureus, Escherichia coli, Pseudomonas aeruginosa, Candidaalbicans, and Streptococcus mutans, have also been used to test the antibacterial effects of endodontic sealers (AlHaddad \& Che Ab Aziz), but Enterococcus faecalis is relevant because several studies report prevalence of up to $77 \%$ in teeth with failed endodontic treatment (Singh et al.). Thus analyzing the antibacterial action of root canal sealers against this bacterium is relevant to clinical practice. Three methods are commonly used to evaluate the antibacterial activity of root canal sealers: agar diffusion test (ADT), direct contact test
(DCT) and modified direct contact test (MDCT) (Poggio et al., 2017; Kapralos et al.).

The aim of this systematic review was to provide knowledge synthesis of the available evidence regarding about antimicrobial properties of bioceramic endodontic root canal sealers in presence of Enterococcus faecalis, specifically evaluated with in vitro studies.

\section{MATERIAL AND METHOD}

Search strategy. An electronic systematic search was performed for available evidence reporting the antimicrobial activity of bioceramic root canal sealers, following the PRISMA checklist (Preferred Reporting Items for Systematic Reviews and Meta-Analyses) (Moher et al., 2009) (Fig. 1). The search was performed using four electronic databases: MEDLINE, ClinicalKey, ScienceDirect and EBSCO (Dentistry and Oral Sciences sources databases). Search was made using a limit of time, between January 2015 and December 2019. The search strategy was made by combining specific search terms related to bioceramic endodontic sealers (examples of the search strategy used are in Table I). Only articles in English were considered. Search results were exported into a Microsoft Excel $\circledast$ table and they were subsequently evaluated.

Study selection. Two reviewers (C.R.N and G.H.O) independently assessed titles and abstracts obtained by the electronic search to select the relevant articles. After the removal of duplicate publications, title reviews, and abstract selection, 13 full-text articles were screened. Full texts of these studies were obtained and analyzed for eligibility by two authors independently (C.R.N and G.H.O). The following inclusion criteria were considered: studies that evaluated the antimicrobial activity of bioceramic root canal sealers, compared with other commonly used endodontic sealers; Enterococcus faecalis was the bacteria used in the antimicrobial evaluation and the antimicrobial activity was evaluated by agar diffusion test (ADT), direct contact test (DCT) or modificated direct contact test (MDCT) in vitro test. Only in vitro studies were considered; no studies in humans were found. Studies that evaluated antimicrobial activity using planktonic cells of Enterococcus faecalis were selected, to avoid possible errors due to misconducted microorganisms detection in bacteria isolated from 
RODRÍGUEZ-NIKLITSCHEK, C.; CHUHUAICURA, P. \& OPORTO, G. H. Antimicrobial activity of bioceramic root canal sealers: A systematic review. Int. J. Odontostomat., 15(2):348-355, 2021.

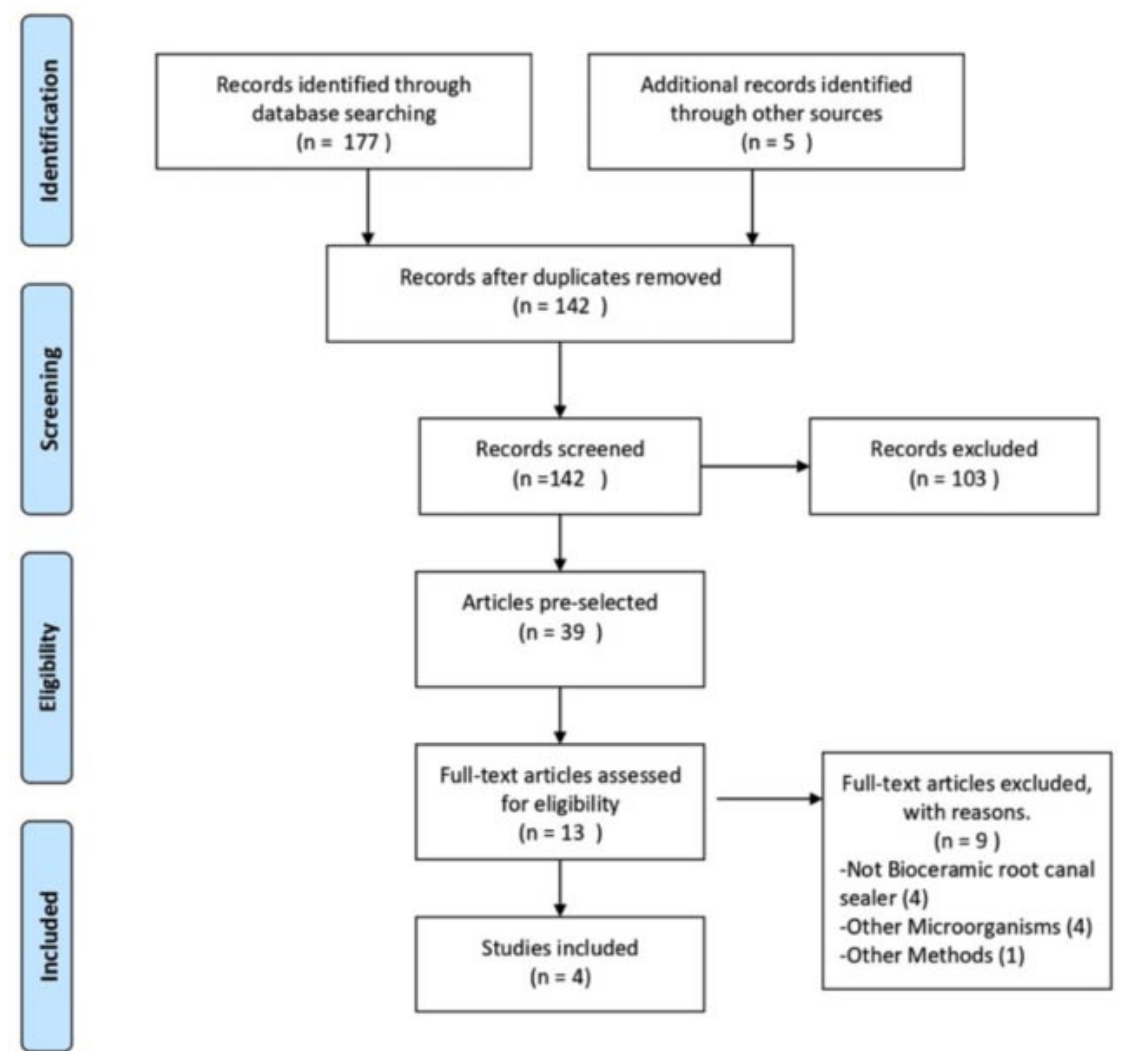

Fig. 1. PRISMA Flow diagram of the systematic review process.

Table I. Example of strategy search combinations used in PubMed.

\begin{tabular}{clc}
\hline $\begin{array}{c}\text { Number } \\
\text { of } \\
\text { strategy }\end{array}$ & Words and terms of search & $\begin{array}{c}\text { Number of } \\
\text { results }\end{array}$ \\
\hline 1 & $\begin{array}{l}\text { bioceramic root canal sealer OR bioceramic root canal sealers OR bioceramic endodontic } \\
\text { sealer OR bioceramic endodontic sealers } \\
\text { antimicrobial activity OR antimicrobial effect OR antimicrobial effectiveness OR antibacterial } \\
\text { activity OR antibacterial effect OR antibacterial effectiveness OR anti-biofilm activity OR anti- } \\
\text { biofilm effectiveness } \\
\text { bioceramic root canal sealer OR bioceramic root canal sealers OR bioceramic endodontic } \\
\text { sealer OR bioceramic endodontic sealers AND (antimicrobial activity OR antimicrobial effect } \\
\text { OR antimicrobial effectiveness OR antibacterial activity OR antibacterial effect OR antibacterial } \\
\text { effectiveness OR anti-biofilm activity OR anti-biofilm effectiveness) }\end{array}$ \\
\hline
\end{tabular}

root canals. Any possible discrepancies in the screening process were resolved via discussion or by involving a third reviewer (P.C). Finally, 4 full-text articles were selected and reviewed by the authors. The reviewers independently identified and categorized the available information in the studies.

Assessment of risk of bias. The methodological quality of the selected articles was evaluated based on the modified Consolidated Standards of Reporting
Trials (CONSORT) for in vitro preclinical studies (Faggion Jr., 2012). Eight parameters were included: intervention, outcomes, sample size, randomization, implementation, blinding, statistical methods and results. Two independent reviewers (C.R.N and G.H.O) analyzed each article. The items received a "Yes" when the authors explicitly described the corresponding parameter; if any information was not available or fully declared the item received a "No". A third reviewer (P.C) resolved discrepancies during the review process. 


\section{RESULTS}

Search and selection. From the electronic search, 182 abstracts were obtained; 39 duplicates and 103 articles not relevant to the topic were eliminated. 39 studies were pre-selected and full texts of 13 studies were evaluated. 9 studies were excluded for non-compliance with the inclusion criteria. Finally, 4 articles fulfilled the inclusion criteria (Candeiro et al., 2016; Singh et al.; Colombo et al., 2018; Kapralos et al.). Selected studies used the materials according to the manufacturer's instructions and recommendations. Authors evaluated growth of Enterococcus faecalis (ATCC 29212 and ATCC 19434) using ADT (Candeiro et al.; Singh et al.; Colombo et al.), DCT (Candeiro et al.; Colombo et al.) and MDCT (Kapralos et al.). The laboratory stages were detailed described in all the studies.

Risk of bias. As mentioned, the methodological quality of the articles included in this research was assessed by checking the CONSORT criteria (Table II). Parameters related to the intervention were described successfully in each article as well as the statistical methods used (100 \%); outcomes were considered in 3 articles (75\%). Items associated with sample size, randomization and blinding were not correctly reported or were not included in the selected articles.

Root canal sealers evaluated. The study performed by Candeiro et al. compared the antibacterial activity between two root canal sealers: EndoSequence ${ }^{\mathrm{TM}}$ sealer (Brasseler, Savannah, GA, USA) and AH Plus ${ }^{\mathrm{TM}}$ sealer (Dentsply International Inc, York, PA, USA). EndoSequence $^{\mathrm{TM}}$ is a premixed bioceramic-based root canal sealer (Camilleri, 2016; Kakoura \& Pantelidou, 2018). AH Plus ${ }^{\mathrm{TM}}$ sealer is a paste-paste system, epoxy resin-based root canal sealer (Candeiro et al.). Sight et al., compared the antibacterial activity of different endodontic sealers. Among them, the bioceramic sealer investigated was also EndoSequence ${ }^{\mathrm{TM}}$ and were considered four root canal sealers with other composition (Singh et al.). Colombo et al. analyzed the biological and the physico-chemical properties of six endodontic sealers. Two bioceramic-based root canal sealers were evaluated: BioRoot ${ }^{\mathrm{TM}}$ (Septodont, Saint-Maur-desFosses, France) and TotalFill ${ }^{\mathrm{TM}}$ (Colombo et al.). Kapralos et al. evaluated the antibacterial effect of four endodontic sealers against bacteria planktonic grown. The bioceramic root sealer included was TotalFill ${ }^{\mathrm{TM}}$. Roeko ${ }^{\mathrm{TM}}$ Seal served as a positive control in this study, because the manufacturer states that it does not possess antibacterial activity (Kapralos et al.). The detail of all root canal sealers evaluated in the four selected studies is showed in Table III.

Antimicrobial activity of endodontic sealers. EndoSequence ${ }^{\mathrm{TM}}$ bioceramic root canal sealer is a premixed injectable bioceramic paste, with hydrophilic properties. Other brands of this type of sealer are TotalFill ${ }^{\mathrm{TM}}$ and iRoot SP ${ }^{\mathrm{TM}}$ (Camilleri; Kakoura \& Pantelidou). Their composition is based on calcium silicate (Debelian \& Trope, 2016; Jafari \& Jafari, 2017). According to the results, the antibacterial activity of this sealer remains inconclusive. Candeiro et al. analyzed their antibacterial activity on Enterococcus faecalis

Table II. Evaluation of the studies using the modified CONSORT checklist (Figgion, 2012).

\begin{tabular}{llllllll}
\hline Author & 1 & 2 & 3 & 4 & 5 & 6 & 7 \\
\hline Singh et al. (2016) & YES & NO & NO & NO & NO & NO & YES \\
Candeiro et al. (2016) & YES & YES & NO & NO & NO & NO & YES \\
Colombo et al. (2018) & YES & YES & NO & NO & NO & NO & YES \\
Kapralos et al. (2018) & YES & YES & NO & NO & NO & NO & YES \\
\hline
\end{tabular}

1) The intervention for each group, including how and when it was administered, with sufficient detail to enable replication.

2) Completely defined, pre-specified primary and secondary measures of outcome, including how and when they were assessed.

3) How sample size was determined.

4) Method and Mechanism used to generate the random allocation sequence.

5) Who generated the random allocation sequence, who enrolled teeth?

6) If done, who was blinded after assignment to intervention (for example, care providers, those assessing outcomes), and how and who assigned teeth to intervention.

7)Statistical methods used to compare groups for primary and secondary outcomes.

8)For each primary and secondary outcome, results for each group, and the estimated size of the effect and its precision. 
Table III. Root canal sealers analyzed in the selected studies.

\begin{tabular}{|c|c|c|c|}
\hline \multirow[t]{2}{*}{ Autor } & \multirow[t]{2}{*}{ Bioceramic root canal sealer } & \multicolumn{2}{|l|}{ Comparison } \\
\hline & & Root canal sealer & Type \\
\hline $\begin{array}{l}\text { Candeiro } \\
\text { et al., } 2016\end{array}$ & $\begin{array}{l}\text {-EndoSequence BC Sealer } \\
\text { (Brasseler, Savannah, GA, USA) }\end{array}$ & -AH Plus (Dentsply International Inc, York, PA USA) & Epoxy resin-based \\
\hline $\begin{array}{l}\text { Singh } \\
\text { et al., } 2016\end{array}$ & $\begin{array}{l}\text {-EndoSequence BC Sealer } \\
\text { (Brasseler, Savannah, GA, USA) }\end{array}$ & $\begin{array}{l}\text { - MM sealer (Micro Mega, France) } \\
\text { - Endoseal (Prevest Denpro, Jammu, India) } \\
\text {-ProRoot white MTA (Dentsply, Ballaigues } \\
\text { Switzerland) } \\
\text { - MM-MTA (Micro Mega, France) }\end{array}$ & $\begin{array}{l}\text { Epoxy resin-based } \\
\text { Zinc eugenol-based } \\
\text { MTA- based } \\
\text { MTA based }\end{array}$ \\
\hline $\begin{array}{l}\text { Colombo } \\
\text { et al., } 2018\end{array}$ & $\begin{array}{l}\text {-BioRoot }{ }^{\mathrm{TM}} \text { RCS (Septodont, Saint } \\
\text {-Maur-desFosses, France) } \\
\text {-TotalFill BC Sealer (FKG Dentair } \\
\text { e SA La C haux_de_Fonds } \\
\text { Switzerland) }\end{array}$ & $\begin{array}{l}\text {-MTA Fillapex (Angelus Dental } \\
\text { Solutions,Londrina,PR, Brazil) } \\
\text {-Sealapex }{ }^{\text {TM }} \text { (Kerr, Orange, CA, U.S.A) } \\
\text {-AH Plus (Dentsply-DeTrey Konstanz Germany) }\end{array}$ & $\begin{array}{l}\text { Polymeric calcium } \\
\text { hydroxide-based }\end{array}$ \\
\hline $\begin{array}{l}\text { Kapralos } \\
\text { et al., } 2018\end{array}$ & $\begin{array}{l}\text {-TotalFill BC sealer (Brasseler USA } \\
\text {, Savannah, GA, USA) }\end{array}$ & $\begin{array}{l}\text {-EasySeal (Komet, Brasseler GmbH \& Co., Lemgo, } \\
\text { Germany) } \\
\text {-AH Plus (Dentsply International Inc, York,PA, USA) } \\
\text {-RoekoSeal (Coltene, Alstätten) } \\
\text {-Guttaflow 2(Whaledent, Altstätten, Switzerland) }\end{array}$ & $\begin{array}{l}\text { Epoxy resin-based } \\
\text { Epoxy-resin sealer } \\
\text { Epoxy resin-based } \\
\text { Silicon -based } \\
\text { Silicon-based }\end{array}$ \\
\hline
\end{tabular}

using two laboratory methods: ADT and DCT. The diameter of the inhibition zones in the first case was measured after 48 hours and the CFU in the second case were counting after $1,24,72$ and 168 hours. The results showed that the inhibition zone of $\mathrm{AH}$ Plus ${ }^{\mathrm{TM}}$ sealer $(10.31 \pm 0.21 \mathrm{~mm})$ was significantly larger than EndoSequence $^{\mathrm{TM}}$ sealer $(6.00 \pm 0.03 \mathrm{~mm} ; \mathrm{p}<0.05)$ (Candeiro et al.). A similar situation was observed in DCT, were Endosequence ${ }^{\mathrm{TM}}$ sealer had significantly smaller antibacterial activity than $\mathrm{AH}$ Plus ${ }^{\mathrm{TM}}$ sealer up to 1 hour of direct contact $(p<0.05)$. On the other hand, the results published by Sight et al. (2016) showed a highest inhibitory activity of EndoSequence ${ }^{\mathrm{TM}}$ $(14.4 \pm 1.49 \mathrm{~mm})$, compared with other endodontic sealers: MM-MTA ${ }^{\mathrm{TM}}(14.3 \pm 0.47 \mathrm{~mm})$ and ProRoot ${ }^{\mathrm{TM}}$ MTA $(13.9 \pm 1.16 \mathrm{~mm})$. The authors suggest that this effect may be attribute to the high $\mathrm{pH}$ released by this material (Singh et al.). However, there were not found statistically significant differences among these materials $(p>0.05)$. Moreover, Endoseal ${ }^{\mathrm{TM}}(0 \mathrm{~mm})$ and MM-seal ${ }^{\mathrm{TM}}(0 \mathrm{~mm})$ did not demonstrated inhibitory effect over Enterococcus faecalis (Singh et al.).

Similar results than observed by Candeiro et al. are published by Colombo et al. These authors, using ADT method, observed that all root canal sealers showed antibacterial activity except TotalFill ${ }^{\mathrm{TM}}$ sealer. In this reseach was included other bioceramic sealer, BioRoot ${ }^{\mathrm{TM}}$. It is a bioactive mineral based on tricalcium silicate, zirconium oxide and Povidone and has been determined that has an acceptable physico-chemical properties. BioRoot ${ }^{\mathrm{TM}}(0.2 \pm 0.05 \mathrm{~mm})$, MTA Fillapex ${ }^{\mathrm{TM}}$ $(0.3 \pm 0.02 \mathrm{~mm})$ and Sealapex ${ }^{\mathrm{TM}}(0.2 \pm 0.04)$ presented the lowest antibacterial activity compared with $\mathrm{AH}$ Plus $^{\mathrm{TM}}$ sealer $(1.20 \pm 0.15 \mathrm{~mm})$ and EasySeal ${ }^{\mathrm{TM}}$ sealer $(8.00 \pm 1.41 \mathrm{~mm})$. However, when using DCT method, for every contact time included in the methodology used ( 6 minutes, 15 minutes and 60 minutes) TotalFill TM has bactericidal effect against Enterococcus faecalis (Colombo et al.). Results published by Kapralos et al. showed that $\mathrm{AH}$ Plus ${ }^{\mathrm{TM}}$ had high antibacterial activity, however it was lost after 24 hours. TotalFill ${ }^{\mathrm{TM}}$ showed marked antibacterial effect on planktonic bacteria up to 7 days after setting and Guttaflow2 ${ }^{\mathrm{TM}}$ and RoekoSeal ${ }^{\mathrm{TM}}$ had no antibacterial activity (Kapralos et al.). This authors used different conditions to examine whether the presence of water can affect the antibacterial properties of this bioceramic sealer (Kapralos et al.). No differences were observed in bacterial survival with or without storage in water. This evidences indicate that the high value of the initial $\mathrm{pH}$ of the endodontic sealers may not be the only factor to explain their antibacterial activity.

\section{DISCUSSION}

The use of root canal sealers materials with antibacterial activity is considered beneficial (Zhang et al.). A root canal sealer with antimicrobial properties may increase the success in endodontics because it 
can contributes in the elimination of residual microorganisms or new microorganisms that can invade the root canal later through microleakage (AlHaddad \& Che Ab Aziz). Studies have been previously performed to assess the antimicrobial activity of different endodontic sealers. However, results of this literature review determined that there is no information available regarding the antimicrobial properties of bioceramic endodontic sealers in general (Zhang et al.). For these reasons was carried out a systematic review for this type of endodontic root canal sealer. The bacterium chosen for the study was Enterococcus faecalis, for several reasons (Du et al., 2015). Within the characteristics of Enterococcus faecalis, could be mentioned that it is a part of the normal oral flora in humans, have been reported that is frequently found in mixed infections, it is one of the microorganisms most commonly isolated from the root canal, usually in secondary infections (Nair et al., 2011), and has been strongly associated with persistent periapical infections and endodontic treatment failures (Rodríguez-Niklitschek \& Oporto; Oporto et al.). The antimicrobial activity of bioceramic root canal sealers was evaluated using in vitro tests reported in the preceding literature. The effect of endodontic sealers on microbial viability has been examined by ADT, DCT and MDCT; ADT is the primary method for determining the antimicrobial activity of medical substances such as endodontic sealers. ADT is a qualitative method, easy to perform and simple (Balouiri et al., 2016; Dwivedi et al., 2017); it is one of the classic techniques of microbiology (Sandle, 2016), and is still commonly used because of its convenience, efficiency, and cost. This is probably one of the most used methods for determining antimicrobial resistance worldwide (Sandle). However, recent studies have demonstrated that there is an important variability in the diffusion capacity of different root canal sealers into the culture media, due to the physic and chemical characteristics of certain components of specific sealers. Thus, the use of ADT is not a method recommended for antimicrobial analysis of endodontic sealers (Kapralos et al.; Bukhari \& Karabucak, 2019). DCT is other alternative, but this method does not considered the dentin structure and its composition and the biofilm formation (Bukhari \& Karabucak). The MDCT is a quantitative and reproducible method, that simulates the contact between the endodontic sealer and the microorganism inside the root canal; it can be standardized to test insoluble materials, like endodontic sealers (Zhang et al.; Ghatole et al., 2016).

The permanence of microorganisms or the recontamination of the root canals may be partly attributed to their ability to penetration into dentinal tubules where biofilms can be formed. Thus, inside the dentinal tubules the bacteria may be protected from the direct antibacterial effect of sealers (Wang et al., 2014a). Although a variety of different models have been used to evaluate the effectiveness of endodontic sealers on planktonic form of microorganisms, the antibacterial activity of endodontic sealers against established biofilms has not been extensively studied (Baer \& Maki). Although the endodontic sealers evaluated (Endosequence ${ }^{\mathrm{TM}}$, Bioroot ${ }^{\mathrm{TM}}$ and Totalfill ${ }^{\mathrm{TM}}$ ) showed antimicrobial activity against Enterococcus faecalis exhibited a decreasing antibacterial activity within a few hours or days after mixing (Wang et al., 2014a).

\section{CONCLUSION}

Finally, the results of this systematic review showed the performance of bioceramic sealers evaluated in vitro, although it was found heterogeneous, depending of the laboratory method used. The antibacterial activity of this sealers seems to be effective at different degrees, for example, in the study performed by Colombo et al. the results of ADT showed lowest anti-bacterial activity for Bioroot ${ }^{\mathrm{TM}}$ compared to the others root canal sealers evaluated, although the limitation of this technique may cause false positive results. In conclusion, evaluated researchshowed that the bioceramic sealers may have various degrees of antimicrobial activity. With this information, it is not possible to make a conclusion about their comparative efficacy or recommend the use of one of them. Clinicians should be careful about the properties of endodontic bioceramic sealers until more evidence exists. Further research is required to compare the efficacy of bioceramic endodontic sealers, ideally in vivo. More reliable methods are needed that considered biofilm formation attached to dentinal root surfaces and the studies on humans are needed for make recommendations for the clinical practice.

\section{ACKNOWLEDGEMENTS}

This study was partially supported by the Dirección de Investigación y Creación Artística, Universidad Mayor, Chile (Fondo Start Up-2017 (OI-101166)) and Dirección de Investigación (DIUFRO), Universidad de La Frontera, Temuco, Chile (DI20-0152). 
RODRÍGUEZ-NIKLITSCHEK, C.; CHUHUAICURA, P. \& OPORTO, G. H. Actividad Antimicrobiana de los Cementos Endodónticos Biocerámicos: Una Revisión Sistemática. Int. J. Odontostomat., 15(2):348-355, 2021.

RESUMEN: En la actualidad, los cementos selladores biocerámicos son una opción ventajosa para la obturación de canales radiculares debido a sus múltiples propiedades. Existen varios estudios in vitro acerca de sus propiedades antimicrobianas, sin embargo, su potencial antimicrobiano, en comparación con otros tipos de cementos selladores endodónticos, no se está completamente claro. El propósito de la presente investigación fue realizar una revisión sistemática sobre las propiedades antimicrobianas de los cementos selladores biocerámicos disponibles en el mercado sobre Enterococcus faecalis, de acuerdo a la declaración PRISMA. Se realizó una búsqueda bibliográfica en cuatro bases de datos electrónicas: MEDLINE, ClinicalKey, ScienceDirect y EBSCO. Se incluyeron estudios in vitro, publicados en inglés, entre 2015 y 2019. La evaluación de los estudios seleccionados fue realizada por dos autores de forma independiente. Fueron incluidos cuatro estudios en la revisión. EndoSequence ${ }^{\mathrm{TM}}$ (Brasseler USA, Savannah, GA), también comercializado en el mercado como TotalFill ${ }^{\mathrm{TM}}$ (Brasseler USA, Savannah, GA), y BioRoot ${ }^{\mathrm{TM}}$ fueron los cementos selladores biocerámicos evaluados. El riesgo de sesgo se evaluó de acuerdo con la lista de verificación CONSORT modificada para estudios preclínicos. Los estudios seleccionados informaron actividadantimicrobiana positiva contra $\mathrm{E}$. faecalis en los selladores biocerámicos evaluados. La menor actividad la presentó BioRootTM. Todos los estudios utilizaron una forma planctónica de $E$. faecalis y métodos de evaluación in vitro. La actividad antimicrobiana reportada varió en base al método de laboratorio utilizado, incluso para el mismo sellador, por lo que se sugiere la existencia de falsos negativos. Esta revisión sistemática identificó la necesidad de realizar más investigaciones sobre la actividad antimicrobiana de los selladores biocerámicos, idealmente con modelos que utilicen biopelículas bacterianas y estudios en humanos.

PALABRAS CLAVE: Agente antiinfeccioso, Bacteria, Biofilm, Endodoncia, Enterococcus faecalis, Sellador del conducto radicular.

\section{REFERENCES}

Al-Haddad, A. \& Che Ab Aziz, Z. A. Bioceramic-based root canal sealers: a review. Int. J. Biomater., 2016:9753210, 2016.

Alshwaimi, E. Evaluation of antimicrobial effect of root canal sealers. Pak. Oral. Dent. J., 31(2):432-5, 2011.

Baer, J. \& Maki, J. S. In vitro evaluation of the antimicrobial effect of three endodontic sealers mixed with amoxicillin. J. Endod., 36(7):1170-3, 2010.

Balouiri, M.; Sadiki, M. \& Ibnsouda, S. K. Methods for in vitro evaluating antimicrobial activity: A review. J. Pharm. Anal., 6(2):71-9, 2016
Bukhari, S. \& Karabucak, B. The antimicrobial effect of bioceramic sealer on an 8-week matured Enterococcus faecalis biofilm attached to root canal dentinal surface. J. Endod., 45(8):1047$52,2019$.

Camilleri, J. Is mineral trioxide aggregate a bioceramic? Odovtos, 18(1):13-7, 2016

Candeiro, G. T. M.; Moura-Netto, C.; D'Almeida-Couto, R. S.; Azambuja-Júnior, N.; Marques, M. M.; Cai, S. \& Gavini, G. Cytotoxicity, genotoxicity and antibacterial effectiveness of a bioceramic endodontic sealer. Int. Endod. J., 49(9):858-64, 2016.

Colombo, M.; Poggio, C.; Dagna, A.; Meravini, M. V.; Riva, P.; Trovati, F. \& Pietrocola, G. Biological and physico-chemical properties of new root canal sealers. J. Clin. Exp. Dent., 10(2):e120-6, 2018.

Debelian, G. \& Trope, M. The use of premixed bioceramic materials in endodontics. G. Ital. Endod., 30(2):70-80, 2016.

Du, T.; Wang, Z.; Shen, Y.; Ma, J.; Cao, Y. \& Haapasalo, M. Combined antibacterial effect of sodium hypochlorite and root canal sealers against Enterococcus faecalis biofilms in dentin canals. J. Endod., 41(8):1294-8, 2015.

Dwivedi, C.; Pandey, I.; Pandey, H.; Ramteke, P. W.; Pandey, A. C.; Mishra, S. B. \& Patil, S. Chapter 9: Electrospun Nanofibrous Scaffold as a Potential Carrier of Antimicrobial Therapeutics for Diabetic Wound Healing and Tissue Regeneration. In: Grumezescu, A. M. (Ed.). Nano- and Microscale Drug Delivery Systems. Amsterdam, Elsevier, 2017. pp.147-64.

Faggion Jr., C. M. Guidelines for reporting pre-clinical in vitro studies on dental materials. J. Evid. Based Dent. Pract., 12(4):182-9, 2012.

Ghatole, K.; Patil, A.; Giriyappa, R. H.; Singh, T. V.; Jyotsna, S. V. \& Rairam, S. Evaluation of antibacterial efficacy of MTA with and without additives like silver zeolite and chlorhexidine. J. Clin. Diagn. Res., 10(6):ZC11-4, 2016.

Jafari, F. \& Jafari, S. Composition and physicochemical properties of calcium silicate based sealers: A review article. J. Clin. Exp. Dent., 9(10):e1249-55, 2017.

Kakoura, F. \& Pantelidou, O. Retreatment efficacy of endodontic bioceramic sealers: a review of the literature. Odovtos, 20(2):3950,2018

Kapralos, V.; Koutroulis, A.; Ørstavik, D.; Sunde, P. T. \& Rukke, H. V. Antibacterial activity of endodontic sealers against planktonic bacteria and bacteria in biofilms. J. Endod., 44(1):149-54, 2018.

Koch, K. \& Brave, D. A new day has dawned: the increased use of bioceramics in endodontics. Dentaltown.com, 39-43, 2009.

Krell, K. F. \& Wefel, J. S. A calcium phosphate cement root canal sealer--scanning electron microscopic analysis. J.Endod., 10(12):571-6, 1984.

Moher, D.; Liberati, A.; Tetzlaff, J.; Altman, D. G. \& PRISMA Group. Preferred reporting items for systematic reviews and metaanalyses: the PRISMA statement. PLoS Med., 6(7):e1000097, 2009.

Nair, U.; Ghattas, S.; Saber, M.; Natera, M.; Walker, C. \& Pileggi, R. A comparative evaluation of the sealing ability of 2 root-end filling materials: an in vitro leakage study using Enterococcus faecalis. Oral Surg. Oral Med. Oral Pathol. Oral Radiol. Endod., 112(2):e74-7, 2011.

Nirupama, D. N.; Nainan, M. T.; Ramaswamy, R.; Muralidharan, S.; Usha, H. H. L.; Sharma, R. \& Gupta, S. In vitro evaluation of the antimicrobial efficacy of four endodontic biomaterials against Enterococcus faecalis, Candida albicans, and Staphylococcus aureus. Int. J. Biomater., 2014:383756, 2014.

Oporto, G.; Soto-Álvarez, C.; Salazar, L. \& Rodríguez-Niklitschek, C. Presence of Enterococcus faecalis is associated to endodontic diagnosis in devitalized teeth. Transylv. Rev., 26:9060-4, 2018.

Poggio, C.; Trovati, F.; Ceci, M.; Colombo, M. \& Pietrocola, G. Antibacterial activity of different root canal sealers against Enterococcus faecalis. J. Clin. Exp. Dent., 9(6):e743-8, 2017. 
Rodríguez-Niklitschek, C. \& Oporto, G. H. Clinical implications of Enterococcus faecalis microbial contamination in root canals of devitalized teeth: Literature review. Rev. Odontol. Mex., 19(3):e177-82, 2015.

Sandle, T. Antibiotics and Preservatives. In. Sandle, T. Pharmaceutical Microbiology. Essentials for Quality Assurance and Quality Control. Cambridge (UK), Woodhead Publishing Limited, 2016. pp.171-83.

Singh, G.; Gupta, I.; Elshamy, F. M. M.; Boreak, N. \& Homeida, H. E. In vitro comparison of antibacterial properties of bioceramicbased sealer, resin-based sealer and zinc oxide eugenol based sealer and two mineral trioxide aggregates. Eur. J. Dent., 10(3):366-9, 2016.

Wang, Z.; Shen, Y. \& Haapasalo, M. Dental materials with antibiofilm properties. Dent. Mater., 30(2):e1-16, 2014b.

Wang, Z.; Shen, Y. \& Haapasalo, M. Dentin extends the antibacterial effect of endodontic sealers against Enterococcus faecalis biofilms. J. Endod., 40(4):505-8, 2014a.

Zhang, H.; Shen, Y.; Ruse, N. D. \& Haapasalo, M. Antibacterial activity of endodontic sealers by modified direct contact test against Enterococcus faecalis. J. Endod., 35(7):1051-5, 2009.
Corresponding author:

Prof. Dr. Gonzalo H. Oporto

Departamento de Odontología Integral Adultos

Facultad de Odontología

Universidad de La Frontera

Av. Francisco Salazar 01145

Temuco

CHILE

E-mail: gonzalo.oporto@ufrontera.cl 